\title{
第42回 日本細菌学会九州支部総会
}

\author{
会 長 中山 宏明 (九州大学歯学部細菌学教室) \\ 期 日 1989 年 9 月13日 (水) $\cdot 14$ 日（木） \\ 会 場 木魂館（熊本県阿蘇郡小国町北里371-1）
}

$$
\begin{aligned}
& \text { 目次 } \\
& \text { シンポジア }
\end{aligned}
$$

1.リケッチアとリケッチア症最近の話題

S 1-1 リケッチア症の生態学的背景……南嶋洋一（宮 崎医大 ·微生物)

S 1-2 わが国の紅斑熱リケッチアについて……田孝 宏 (徳島大・医・ウイルス)

S 1-3 Q 熱の病原リケッチア Coxiella burnetii の分離 とその性状……田 紘(鹿児島大·医・細菌)

S 1-4 Rickettsia tsutsugamushi に関する基礎微生物学 的研究最近の知見……多村 憲 (新潟薬大 ·微 生物)

\section{2. 明日のワクチンの胎動}

S 2-1 汎用サルモネラ組換え型生菌ワクチンの開発… …中山浩次（九大·歯・細菌）

S 2-2 コレラと関連下痢症ワクチンの開発研究 : 細菌 学から見た粘膜局所免疫の最前線……立本達男 （順天堂大·医・細菌）

$\mathrm{S} 2-3$ らいワクチン開発の現状と将来……水口康雄 （産業医大・微生物）

\section{一般演題}

I - 1 狂犬病ウイルス街上毒感染による細胞性免疫抑 制機序について……河野 宏, ○三舟求畺人, 万年和明, 平松和史, 平井一弘, 七条明久（大 分医大·微生物)

I - 2 酵素補体染色法によるウイルス抗体の測定…… ○南嶋洋一, 龍美弥子（宮崎医大·微生物）

I - 3 各種神経疾患患者末梢血単核球の HTLV-I プ ロウイルスの検索……宮本 勉, 中山大介, 片峰 茂, 川瀬健一郎，金沢一1)，渋谷統
寿1)，日野茂男（長崎大・医・細菌，1）国療川 棚病院)

I - 4 細菌感染局所の痛みと浮腫はなぜ起こるか？‥ …前田 浩（熊本大·医・微生物）

I - 5 Legionella pneumophilaのマクロファージ内増 殖を抑制するマウスの遺伝支配について……... ○吉田真一, 後藤義孝 ${ }^{1)}$, 水口康雄, E. Ska$\mathrm{mene}^{2)}$ (産業医大 · 微生物, ${ }^{1)}$ 予研 $\cdot$ 細胞免疫, ${ }^{2)}$ Montreal General Hospital)

$\mathrm{I}-6$ 白血球の殺菌物質…… 小橋 修, 守屋哲博, 天児和暢（九大・医・細菌）

I - 7 Acholeplasma laidlawii の抗腫瘍作用……荒 井澄夫, 合原幸子, 桑野剛一, 宗像哲男, 福勢 智（久留米大·医・細菌）

I - 8 Candida albicans の germ tube 形成と菌体内 cyclic AMP ……長 環, 浜高家尚子, 田 中雅子, 上西秀則, 萩原義郷（福岡歯大·口腔 細菌)

I - 9 Candida albicans の付着と細胞表面疎水性….... $\bigcirc$ 新見昌一, 神山章子, 徳永美知子（鹿児島大 . 歯. 細菌)

I -10 Candida albicans のヒト頪粘膜上皮細胞への付 着……徳永美知子, 新見昌一, 小池紘民 ${ }^{1)}$ (鹿 児島大・歯・細菌，1）明石ビームテクノ口 ジー)

I -11 NMR による Candida albicans ステロール変異 株のグルコース代謝の解析……下川 修, 河 野敬一1)，中山宏明（九大・歯・細菌，1）補綴 I )

II - 1 Pseudomonas aeruginosa の萊膜……横山 哲, 梅田昭子, 天児和暢（九大·医・細菌）

II - 2 急速凍結置換法による黄色ブドウ球菌萊膜の電 顕的観察……有薗 剛, 梅田昭子, 天児和暢 （九大·医 ·細菌） 
II - 3 SDS 処理による spirosome たんぱく局在部位 の検討……文吉盛健, 小田 紘（鹿児島大 · 医・細菌)

II - 4 コレラ菌の赤血球凝集阻害因子…… Sumaruno, 江原雅彦, 宇都宮明剛, 一瀬休生, 霜鳥 翔一1)（長崎大 · 熱研 · 細菌, 1) 九大 ·医短 微生物)

II - 5 コレラ菌の赤血球凝集素……江原雅彦, Sumaruno, 宇都宮明剛，一瀬休生，霜鳥翔 -1)（長崎大 · 熱研 · 細菌, 1) 九大 · 医短 ·微 生物)

II -6 腸炎ビブリオの $\delta \mathrm{VPH}$ の病原性の検討…........... ○谷口初美，小川みどり，吉田真一，大友信 也吕, 水口康雄（産業医大·微生物, 1)大分県 公衛センター）

II -7 食品の赤痢菌検査法の検討 $\cdots \cdot . \cdot$ 霜鳥翔一, 天 児和暢1），小島夫美子（九大・医短・微生物， 1)九大 · 医 · 細菌)

II -8 胆汁酸 $7 \alpha$-脱水酸化反応陽性株について…......... ○高嶺房枝, 今村禎祐（琉球大·医·保健）

II -9 ハマチレンサ球菌感染症原因菌, Streptococcus $\mathrm{sp}$. , 由来 $\mathrm{R}$ プラスミドの薬剤耐性遺伝子につ いて…ㅇ.高見幸司，青木 宙，北尾忠利（宮 崎大 ·農 · 水産衛生)

II -10 豚鼻腔由来 Pasteurella multocida の R プラス ミ ドの検索……牛島稔大，永野理恵，河合 透，種子野章，花木玩磨，江藤正信（化血研）

II - 11 レイ菌線毛遺伝子の解析……守屋哲博, 山本 松男，天児和暢（九大·医・細菌）

II -12 新たにクローニングしたAeromonas hydrophila の溶血素遺伝子について…‥広野育生，青木 宙, 北尾忠利（宮崎大·農·水産衛生）

II - 13 大腸菌 RecQ たんぱくの精製およびその活性に つててDNA 依存性 ATPase 活性と helicase 活性-……梅津桂子, 中山浩次, 中 山宏明（九大・歯・細菌）

II-14 チミン飢餓の大腸菌染色体 DNA への影響 : ハ ルスフィールド電気泳動法による解析……草野 好司，○中山浩次，中山宏明 (九大·歯・細菌)

\section{要旨 \\ シンポジア}

1.リケッチアとリケッチア症最近の話題

S 1-1 リケッチア症の生態学的背景

南嶋洋一（宮崎医大・微生物）

一般に，ある地域の自然環境の特徵と，その地域の住 民の生活様式が密接に係わり合つて生ずる疾患は風土病 とよばれる。リケッチア症の多くは風土病的性格が強 い。日本海に面する秋田，山形，新潟三県の河川敷は， ツッガムシの生息地であると同時に，農民にとつては貴 重な耕作地でもあつた。したがつて両者は必然的に接触 した。ッッガムシはその生活史の中で卯化直後の幼虫 （6 脚）の時期に一度だけ地上に出て，そこに生息する 一種一個体の脊椎動物 (ネズミ，ヒトなど) に寄生する。 皮膚に吸着したツッガムシは唾液線の分泌物を皮膚に注 入して, stylostome (feeding tube)を作り，それを通 して、唾液の注入と組織液の吸引を繰り返す。この時唾 液中のリケッチア・ツツガムシがヒトに伝達され，恙虫 病が引き起こされてきた。そして，リケッチア・ッッガ ムシを媒介するッッガムシのみが，真皮に達する stylostome を形成することが知られている。

恙虫病は，しかし，今や東北地方に限局することな く, 日本各地はもとより, ニーラシア大陸の東南部から 大洋州にかけて発生する広域疾患として認識されてい る。これらの流行地ではリケッチア・ツッガムシ，ケダ 二類，ネズミ類の分布が重なり合ら。

一方, リケッチア・ツッガムシは恙虫病の発生地域を 越えて分布するが，北米，南米大陸にはまだ存在する証 拠はない。これに対して、紅斑熱群リヶッチアの場合 は，保有および媒介動物であるマダ二類ともども北米， 南米大陸を含む全世界に分布し，特定の地域にそれぞれ 固有の種が定着している。事実，わが国においても，最 近内田らにより紅斑熱の存在が初めて明らかにされ, 新 種のリケッチアが分離された。コクシェラ・バーネティ も世界的に分布しており，人獣共通感染症である $\mathrm{Q}$ 熱 をひきおこすが，その伝播は必ずしも節足動物に依存し ない点が特異である。したがつて家畜の移動，食肉の輸 入などによつて拡散する。わが国においては，最近初め て，海外で実験動物より感染したものと考えられる $\mathrm{Q}$ 熱の例が小田らにより報告された。

このように, リケッチアの地理的分布上の特徵は, リ ケッチアの出現と拡散が地球の歴史, 動物相, 人間の生 
活様式と深くかかわつていることを示している。そし て, リケッチア症は, リケッチアが節足動物との共生 と，それによる存続を求める進化の過程で生じた，偶発 的な事態の一つであろ5。今回は，とくに恙虫病を中心 に,リケッチア症の生態学的背景を文献的に遠望し, 地 理的分布の意義を論じてみたい。

\section{S 1-2 わが国の紅斑熱リケッチアについて}

内田孝宏 (徳島大·医・ウイルス)

わが国では紅斑熱群リケッチアによる感染症は知られ ていなかつたが, 1984 年, 徳島県阿南市の熱性発疹性 疾患が紅斑熱リケッチア症であることが明らかになつ た。これは Weil-Felix (WF) 反応の臨床検査成績が発 端となつた。当時, WF 反応は信頼性に欠けるとされ ていたが，その検討により本疾患を推定した。

本疾患が紅斑熱リケッチア症であることを確定するた めに, 病原体の分離を試みた。高知県室戸市の患者より 血液を採取し，急速凍結して超低温槽に保存し，Vero 細胞を用いる細胞培養法により効率よく病原体を分離す ることに成功した。現在まで 11 例中 10 例の患者から 病原体を分離している。

分離株はVero 細胞に持続感染し，この点は他の紅斑 熱群リケッチアと相違した。電䫓観察では, リケッチア は透明帯に包まれて宿主細胞の細胞質内にみられ, 細胞 壁は薄い外層と厚い内層からなり, 紅斑熱群りケッチア の細胞壁構造を示した。

分離株の同定のため，分離株 5 株間および既知の紅 斑熱群リヶッチアとの間の抗原特異性差 (Specificity difference : SPD) を検討した。リケッチア感染細胞を接種 してマウス免疫血清を作製し、リケッチア抗原を用いて 相互交差反応を行い, 蛍光抗体法により抗体価を測定し てSPDを求めた。その結果, 分離株間には抗原特異性 に差はみられず，分離株は同一種に属することが明らか になつた。一方，分離株と既知の紅斑熱群リケッチアと の間には抗原特異性に差が認められ，分離株は新種と判 定した。Western blot法による解析でも，分離株は既 知の病原性紅斑熱群リケッチアとは異なることが示され た。さらに, 単クローン抗体の反応性からも分離株は新 しい種であることが支持された。この新種を Rickettsia japonica と命名した。

紅斑熱リヶッチア症は四国東南部の沿岸地方のほか九 州南部, 千葉県南部にもみられ, さらに島根県出雲地方 にも認められた。最近, 兵庫県の淡路島にも患者の発生 が報告されている。紅斑熱リケッチアの地理的分布をみ
ると，地球上の自然の境界により区分された動物地理区 に一致している。R. rickettsii は新熱帯区， R. conorii は 旧北区西南部からェチオピア区， R. sibiricaは旧北区の ウラル山脈以東, $R$. australis はオーストラリア区に分 布している。東洋区では未だ病原性紅斑熱りヶッチアの 報告はない。 $R$. japonica は東洋区のリヶッチアと推測 される。

\section{S 1-3Q 熱の病原リケッチア Coxiella burnetii の分離とその性状}

小田 紘（鹿児島大·医・細菌）

$\mathrm{Q}$ 熱はリケッチア属の一種である Coxiella burnetii に よつて起こる急性熱性疾患である。本疾患は 1935 年に オーストラリアで屠場従業員のあいだに発生した原因不 明の熱性疾患として Derrickにより記載された（Q中 query の頭文字)。1937 年に Burnet らにより病原体と してリケッチアが分離された。その後, 1938 年にアメ リカでCoxらによりマダニから分離されたリケッチア も同一のものであることがわかつたが，この病原体は種 々の点で他のリケッチアと異なる性状を示すことから Philip により Coxiella burnetii と命名され, 従来のリヶ ッチア属と区別されている。

C. burnetii のもつュニークな特徵としては, (1)相変異 を起こし, I 相と II 相では抗原性, 病原性, 培養細胞 での増殖性等が異なり, (2)著しい多形態性を示し, 芽胞 様の構造をとる場合もあり, (3)宿主細胞の phagolysosome 内でリソソーム酵素の作用に耐えて増殖し, (4) 物理的処理や化学薬剂に抵抗性が強く, (5)感染の伝播に 節足動物の媒介を必ずしも必要としない, などがあげら れる。C. burnetii は全世界に分布しているといわれて いるが，これまで日本国内での確実な自然発生例の報告 はない。

われわれは, 留学先のカナダで動物実験中に感染し, 帰国後発症したと考えられる $\mathrm{Q}$ 熱の症例を経験し，患 者血液からC. burnetiiを分離した。分離は cyclophosphamide (CPA) 処理マウスを用いて成功したが, その後の実験で CPA 非処理マウスではこの分離株によ る発症がみられず, 増殖能も低いことがわかつた。即 ち, この分離株はマウスに対して弱毒性であつた。一般 にC. burnetii の分離にはモルモットが最適で, マウスに 対しては株による病原性の差が大きいといわれている。 しかし, CPA 処理マウスでは弱毒株もよく増殖し, 分 離に有用であることが示された。一方，ヌードマウスで は予想された程の増殖はみられなかつた。このことは 
C. burnetii の感染防御機構の解明に 1 つの手掛かりをあ たえるものと考えられる。

本疾患は発疹等の特徵的な症状を示さないため,イン フルェンザ等，他の熱性疾患と誤診され見逃されている ケースが非常に多いといわれている。したがつてわが国 にはもともと本疾患が存在していなかつたのか，また現 在も国内での污染はないのかなどについては不明で，こ の点に関しての血清疫学的な調査を検討中である。

\section{S 1-4 Rickettsia tsutsugamushiに関する基礎} 微生物学的研究最近の知見

多村 憲（新潟薬大・微生物）

恙虫病とその病原体である $R$. tsutsugamushi の発見は わが国先駆者達の輝かしい研究業績によることは周知の 通りである。そしてその後も多数のわが国の先人達が活 発な研究を展開した分野であつたが，昭和 40 年代に患 者発生数が激減したことやウイルス学の新しい展開に伴 つて多数の微生物学者がその方面に転向したことなどに より,リケッチアの研究は一時期放置される状態となつ た。しかし昭和 50 年代に入つてから全国各地で恙虫病 患者発生が報告されるようになり，再度このリケッチア 症が注目されるよらになつた。

演者は奇しくも昭和 53 年にわが国におけけリケッチ ア研究のルーツともいらべき新潟に赴任することとな り，恙虫病リケッチアに関する研究を開始することとな つた。今回はこの 10 年余のわれわれの研究成果を中心 に，一部にわれわれが関係する方々との研究成果を参照 しながら，次の項目の順にご紹介して，ご批判を仰ぎた w。

1. R. tsutsugamushi の細胞内増殖機構についての形 態学

2. ツッガムシ中での R. tsutsugamushi の垂直伝播に ついて

3. R. tsutsugamushi の分離と血清型

i ) 血清型

ii ）血清型と地域性

iii）血清型とマウスに対する病原性の強弱との関連 性

4.R. tsutsugamushi のたんぱく構造と型特異抗原

5.R. tsutsugamushi と他のリヶッチアとの特徵的差 異

6. 患者血清中に産生する抗リケッチア抗体の性状

7 . 新しい恙虫病血清診断法の開発研究

\section{2、明日のワクチンの胎動}

S 2-1 汎用サルモネラ組換え型生菌ワクチンの開 発

中山浩次（九大・崡・細菌）

既存の生ワクチン株に異種の病原微生物の病原因子 （毒素，線毛，表面抗原，等）をコードする遺伝子を組 込み, ワクチン株内で発現させ，生ワクチン株自体に対 してのみでなく導入された異種の病原体の病原因子に対 しての免疫を誘導するタイプの組換え型生ワクチンの開 発研究が近年, 種々の生ワクチン株をベースとして行わ れてきている。

Salmonella typhimurium はげつ歯類に腸チフス様症状 を抗こし，各種の免疫（体液性免疫，細胞性免疫，粘膜 免疫）を誘導する。ヒトには食中毒症状をおこす。 $S$. typhi による腸チフスの動物モデルとして S. typhimurium の病原性に関する研究は盛んであり, 生ワクチ ン株となりらる株も数種開発されている。サルモネラ菌 生ワクチン株を宿主とした組換え型ワクチンの試みとし てはすでに Shigella sonnei $\mathrm{O}$ 抗原, E. coli LT-B, ネズミ マラリア原虫 circumsporozoite 抗原タンパク等の遺伝 子を組込んだ例がある。

通常, 異種の病原体の病原因子をコードする遺伝子を サルモネラ菌に導入する際にはプラスミド DNA がその 遺伝子の運び手 (carrier) として利用されてきた。しか し，プラスミドをこの種の目的で使用するには二つの問 題を克服しなければならない。第一はプラスミドの不安 定性（宿主菌からの脱落）である。第二は一般的に使用 されるべクタープラスミドは薬剤耐性遺伝子をそのマー カーとして有していることである。

これらの二つの問題点を解決するため, 新しい宿主菌 ーベクタープラスミド系を開発した。

1）宿主サルモネラワクチン株への $\Delta a s d$ 変異の導入： asd 遺伝子は細胞壁の構成要素の一つであるジアミノピ メリン酸 (DAP) の生合成に関与する遺伝子であり, asd 変異株は DAP のない環境（生体内は DAP は存在 しない）では細胞溶解を伴ら細胞死を起こす。

2) $\mathrm{Asd}^{+}$プラスミドの作製：野生型 asd 遺伝子を マーカーとしてもつベクタープラスミドであり，asd変 異株に導入すると DAP 非存在下でも増殖可能となる。 宿主菌の生存は $\mathrm{Asd}^{+}$プラスミドの保有に依存する。さ らに, このプラスミドは外来遺伝子を効率よく発現させ るための発現ユニットと multiple cloning siteをむつ。

この宿主菌一ベクタープラスミド系を用いた応用例と ともに既存の組換えプラスミドの安定化のために直接使 
用できる $\mathrm{Asd}^{+}$カートリッジ DNA $\mathrm{TnAsd}^{+}$トランス ポゾンの開発についても紹介する。

\section{S 2-2 コレラと関連下痢症ワクチンの開発研究 :} 細菌学から見た粘膜局所免疫の最前線

山本達男（順天堂大·医·細菌）

1. Live vaccines are not dead. 2. Dead vaccines are still alive. 3. Parenteral vaccines are dead-but perhaps should be live.

これは, Richard A. Finkelstein 博士がュレラワクチ ン開発での長い苦悩の道程を表現した言葉であつた。今 日，われわれは腸管局所での免度成立と感染予防に関し て確固たる自信を持つと同時に，研究の方向を合理的に 設定する幾つかの key wordsを手に入れることが出来 るよらになつた。これは以下の知見の集積によるもので ある。

1. 腸管粘膜には, membrane associated lymphoid tissue (MALT) の一つである gut associated lymphoid tissue（GALT: 消化管リンパ装置）が分布し，分泌型 IgA を粘膜上に産生して生体防御の任にあたつている。 その主役を担つているのが Peyer 板（あるいは孤立り ンパ小節）で, 上皮に $\mathrm{M}$ 細胞を配して腸管腔内の病原 体（抗原）を摂取し，下方のマクロファージあるいはリ ンパ細胞に抗原提示する (Owen ら， 1974 ; 他)。IgA 産生形質細胞の誘導, homing, ヘルパー $\mathrm{T}$ 細胞やサプ レッサー T 細胞の役割, 分泌型 IgA の形成過程, Ia (HLA-DR) 陽性細胞の機能さらに病原体と $\mathrm{M}$ 細胞の粘 着（付着）機構にメスが入れられつつあり，粘膜局所免 疫の全体像が浮彫りにされつつある。

2.「局所性感染症の予防にはワクチンの局所接種が より望ましい」。コラワクチンの場合にもこのコンセ ンサスが有効であつた。怒涛の勢いを見せた組換え DNA 技術を背景として経ロコレラ生菌ワクチンが作製 された (Mekalanos ら, 1983 ; Kaper ら, 1984)。そ の有効率は $90 \%$ 以上と良好なもの (Levine ら，1988) で, 経ロコレラワクチンの有効性を実証した。

3.コレラトキソイド（コレラ毒素 CT の B サブュ ニット）には, 粘膜局所免疫で効果を表わすアジュバン ト作用がある (McKenzie \& Halsey, 1984 ; Elson ら 1984 他; Nedrud ら, 1987 他)。経ロコレラ死菌ワク チンの場合にも，コレラトキソイドとの混合が有効であ つた (Clemens ら， 1986)。CT-BょりCTに, 混合時 より結合時により高いアジュバント効果が期待される。 CT-B あるいはCT が示すアジュバント作用の機序の解
明が進められている。

4. 病原体と宿主（ヒト）の粘着は, 病原体の粘着因 子 (adhesin) と宿主（標的細胞）表面のレセプターを介 して行われる。コレラ菌のヒト小腸での粘着標的は, (1) 粘液層, (2) Peyer 板上皮細胞, (3)絨毛吸収細胞である (Yamamoto \& Yokota, 1988 他)。コレラ菌粘着因子は ヘマグルチニン (HA) (Jones \& Freter, 1976; Yamamoto \& Yokota, 1988 他) あるいは線毛 (Taylor ら，1987；Ehara ら，1987）である可能性が高い。

ヒトはコレラ菌の主要な natural reservoir (host) で ある。上記の key words を駆使して有効なコレラワク チンが作製され, 近い将来コレラ根絶宣言がなされると 素晴らしいと思う。

\section{S 2-3 らいワクチン開発の現状と将来}

水口康雄（産業医大·微生物）

現在，世界には発展途上国を中心に 1 千万から 1 千 5 百万人のらい患者が存在するといわれている。これらの らい患者に対しては，これまでDDSやリファンピシン による化学療法が行われてきたが，最近新しくワクチン による予防あるいは治療が考えられるようになつてきて いる。

らいの病原体であるらい菌は未だ人工培養ができない 菌として有名であるが，その性状から Mycobacterium に 属すると考えられている。同じ属に属する菌である結核 菌の感染に対してはその有効性に多少の疑問は残るもの のBCG がワクチンとして昔から使われて来たが，この BCG の投与がらいの予防にもある程度有効であるとい う報告がいくつかなされている。

近年, アルマジロを用いて比較的大量のらい菌を入手 することが可能になり，これを用いて菌体成分や免疫原 性の研究, 大腸菌の宿主・ベクター系による抗原たんぱ く遺伝子のクローン化などが行われるよ5になつてき た。それに加えて, らい菌の加熱死菌を BCG 生菌と共 にらい腫型らい患者に投与したところ, 多くの患者に細 胞免疫が誘導され, 治癒もしくは症状の軽減がみられた といら Convitらの報告が現われ，らいのワクチン開発 の可能性が一挙に浮上することになつた。

らいワクチンにはこのように治療効果を期待する免疫 療法的な側面と, 感染あるいは発病前の健康者に投与し て発病阻止を狙ら予防効果の 2 つの面が期待される。 しかし抗原の供給が現在のところ感染アルマジロに限ら れているため, 全世界からの要求を満たすことはとうて い不可能といわざるを得ない。 
一方大腸菌の宿主・ベクタ一系を用いてこれまでいく つかのらい菌の抗原たんぱくを作らせることが可能とな つた。これらのたんぱくのいくつかはらい患者などの Tリンパ球と反応し, 感染防御免疫に何らかの役割を 演じている可能性が示されているが，単一のたんぱく抗 原のみで感染防御免疫を十分なレベルにまで誘導できる か否か不明であることに加え, らい菌遺伝子の情報発現 に必ずしも適していない大腸菌で大量の抗原を作らせる ことは困難であろらと考えられる。そこでらい菌と共通 抗原性も有している BCGにらい菌の感染防御に重要な 役割を演じる遺伝子を組み込んで有効なワクチンにしよ らといら研究がスタートすることになつた。これらの研 究の現状について紹介する予定である。

\section{一般演題}

I - 1 狂犬病ウイルス街上毒感染による細胞性免疫 抑制機序について

河野 宏, $\bigcirc$ 三舟求眞人，万年和明，平松和史，平井 一弘，七条明久（大分医大・微生物）

狂犬病ウイルス感染後のワクチン投与による発症防御 には, そのワクチンに抗体産生能に加えて, 細胞性免疫 能があることが不可欠である。一方, 街上毒のみでは, 抗体産生はおこるが, 非特異的細胞性免疫抑制がおこり 死亡する。本研究では, その抑制の成因解明のため, 2, 3 の実験を行い次のような結果をえた。(1)街上毒感染 マウス脾蔵細胞はConA に対する反応性が減弱し, IL2 産生能が低下している。(2)街上毒感染マウス血清に IL-2 産生を抑制するインヒビタ一様物質が増加する。

(3)この物質は IL-2 活性を阻止するものではない。(4)街 上毒感染マウス脾蔵細胞の Lyt2+ 細胞により, 細胞性 免疫抑制の養子伝達が可能である。(5)上記の脾臓細胞は in vitro で CTL 前駆細胞の CTL への分化を抑制する。 (6)街上毒感染マウス脾蔵細胞の $\mathrm{T}$ 細胞分画の in vitro 培 養上清に，血清中に見られたものと同様の IL-2インヒ ビター様活性が存在する。以上の結果から, 街上毒感 染, サプレッサーT 細胞の出現, この細胞による IL-2 産生インヒビタ一の産生増加, IL-2 の産生抑制, 細胞 性免疫抑制という図式が抑制機構の 1 つである可能性 が考えられた。

\section{I- 2 酳素補体染色法によるウイルス抗体の測定} ○南嶋洋一, 龍美弥子（宮崎医大·微生物） サイトメガロウイルス ( CMV) の感染細胞には,
IgG の Fc を結合する糖たんぱく（いわゆるFcレセプ ター）が誘導され, 主として細胞内封入体の部位に局在 する。この Fcレセプターは, 間接免疫ペルオキシダー ゼ法 (IIP) あるいは間接免疫蛍光法 (IIF) に際して, IgG と非特異反応をおこし偽陽性の原因となる。われわ れは, 免疫複合体に結合する補体成分 (Clq) をペルオキ シダーゼで標識したものを用いる酵素補体染色法 (HRPC) による CMV 抗体測定とそれにより測定し得 る抗体を検討して以下の成績を得た。

(1) HRPC は, IIP と対照的に, IgGの Fcレセプ ターを非特異的に染色しない。(2) HRPCは, 同じく Fc レセプターを回避し得る抗補体免疫ペルオキシダーゼ法 (ACIP) と比較して, 操作を一段階短縮し得る。(3)抗体 価は IIP, ACIPより低い。(4)レンサ球菌 (ARI) 菌体処 理と組み合わせると， IgM 抗体を測定し得る。

このよらに, HRPC はウイルス感染初期の抗体検出 法の一つとして有用であろう。

\section{I - 3 各種神経疾患患者末梢血単核球の HTLV-I} プロウイルスの検索

○宮本 勉, 中山大介, 片峰 茂, 川瀬健一郎, 金沢 一1), 渋谷統寿1), 日野茂男（長崎大·医・細菌, 1)国 療川棚病院）

Human T-lymphotropic virus type 1(HTLV-I) は成人 $\mathrm{T}$ 細胞白血病の原因ウイルスであるが, 最近 tropical spastic paraparesis (TSP), HTLV-I associated myelopathy (HAM), そして多発性硬化症 (MS) 等, 中权神経疾患との関連が報告されている。しかし MS については否定的な結果も報告され，その真疑は不明で ある。

われわれは HTLV-I 流行地である長崎県で発生した HAM, MS を含む 7 種の神経疾患 30 症例について HTLV-I との関連を検討した。即ち患者末梢血単核球よ り DNA を抽出し，HTLV-I 関連 DNA 配列の有無を HTLV-I LTR (U3, U5), gag, pol, env および pX 領域を 標的とする polymerase chain reaction (PCR) 法を用い て検索した。

その結果， 30 例中 7 例から HTLV-I 関連 DNA 配列 が検出された (HAM 4 例中 4 例, MS 8 例中 2 例, 重 症筋無力症 : MG 7 例中 1 例)。このうち HAM 3 例, MS 1 例からは上記全 6 領域, HAM 1 例からはenvを 除く 5 領域, MG 1 例からはU3 を除く 5 領域の DNA が検出された。以上 6 例は抗 HTLV-I 抗体も陽性であ つた。残る MS 1 例は抗体陰性で U3 の PCR のみ陽性 
であつた。

この結果, HTLV-I はHAM とは密接に関連してい るが，MSを含め少なくとも調べたその他の疾患との 関連は否定的であつた。

\section{I - 4 細菌感染局所の痛みと浮腫はなぜ起こるか ?}

前田 浩（能本大·医·微生物）

われわれはこれまでセラチア菌, 緑膿菌等の産生する プロテアーゼが，モルモットの皮膚の系と，精製した酵 素系 (in vitro) の両方の実験から，これらプロテアーゼ が皮膚組織中に存在するハゲマン因子 (Hf) を活性化し $(\rightarrow \mathrm{Hfa})$ [第一段]，ついでHfa がプレカリクレインを カリクレイン $(\mathrm{KK})$ 変換 [第二段〕, 生じた $\mathrm{KK}$ が高分 子キニノーゲンを限定分解し，ブラジキニンを産生する 〔第三段〕ことを見出した。

今回, 11 種の各種微生物プロテアーゼについて詳細 に検討したところ，すべてのプロテアーゼは第三段の反 応は行つたが，七ラチア，緑膿菌，アスペルギルスなど のプロテアーゼは第一段の反応のみ，ビブリオプロテ アーゼ，サブチリシンおよびサーモライシン等は第一段 と第二段の両反応を促進した。これらの多くは血中のプ ロテアーゼ阻害剤を容易に分解し，キニン産生カスケー ドをより容易に活性化した。このようにして生じるキニ ンは痛みの原因物質であるとともに浮腫を誘発すること が知られている。このことによつて，標題にある細菌感 染局所の痛みと浮腫が生ずる理由をよく説明することが できる。

\section{I - 5 Legionella pneumophila のマクロファー} ジ内増殖を抑制するマウスの遗伝支配について

○吉田真一, 後藤義孝 ${ }^{1}$, 水口康雄, E. Skamene ${ }^{2)}$

(産業医大·微生物, ${ }^{1)}$ 予研・細胞免疫, ${ }^{2)}$ Montreal General Hospital)

L. pneumophila は $\mathrm{A} / \mathrm{J}$ 亲マウスのチオグリコレートで 誘導した腹腔マクロファージ ( $\mathrm{Mp})$ 内で増殖するが, その他の系統のマウスの $\mathrm{Mp}$ 内では増殖しない。その 遺伝支配を調べるために， $\mathrm{A} / \mathrm{J}$ と $57 \mathrm{BL} / 6$ の交配によ り $(\mathrm{BxA}) \mathrm{F}_{1}, \mathrm{AxF}_{1}$ backcross, $\mathrm{BxF}_{1}$ backcross, $\mathrm{F}_{2}$ を用意 し, さらに Recombinant inbred (RI) strain を用いて, これらのチオグリコレート誘導腹腔マクロファージ内で の本菌の増殖をしらべた。菌は in vitro で貪食させ，経 時的なコロニーカウントと Gimenez 染色により増殖の 有無をみた。その結果 $\mathrm{F}_{1}, \mathrm{BXF}_{1}$ は性に関係なく増殖は みられず， $\mathrm{AXF}_{1}$ は增殖と抑制がほぼ 1:1に， $\mathrm{F}_{2}$ では
現在のところ $4: 1$ に解離した。このことより本菌の Mp 内増殖を抑制する遺伝子は恐らく one gene で優性 であり，常染色体上にあると考えられた。さらにRI strain を使つて解析中である。

\section{I - 6 白血球の殺菌物質}

○小橋 修, 守屋哲博, 天児和暢（九大·医 · 細菌）

貪食細胞は酸素非依存性殺菌物質として，ディフェン シンと呼ばれるアミノ酸 29-32 個の低分子量塩基性ぺ プチドを持つている。ラットの腹腔浸出白血球を超音波 処理し, 48 時間 $0.2 \mathrm{M}$ 酢酸で抽出されたものを Sephadex G100で分画しディフェンシンを精製した。 SDS-PAGE の成績から, 幅広い分画としてディフェン シンが精製された。Lysozyme がごく微量入つていた。 グラム陰陽性菌に幅広い殺菌能を示し, S. typhimurium の変異株 $\mathrm{Ra}, \mathrm{Rc}, \mathrm{Rd}, \mathrm{Re}$ のいずれの株にも, LPS の糖鎖の長さによらず強い殺菌能を示した。殺菌 能は pH6-8 では変化しないが，塩濃度で強く抑制され た。ヒトのディフェンシンの殺菌能は $\operatorname{Re}>\operatorname{Rc}>\operatorname{Ra}$ で $\mathrm{Ra}$ 株には無効であるが, ラットではほぼ同等かむしろ $\mathrm{Ra}$ に強い殺菌能を示した。ラットディフェンシンが特 殊なのか，あるいはごく微量共存していると思われる lysozyme との相乗作用があつたのか不明である。相乗 効果とすればたいへん興味があり，さらに精製し検討し たい。

\section{I - 7 Acholeplasma laidlawii の抗腫瘍作用}

○荒井澄夫, 合原幸子, 桑野剛一, 宗像哲男, 福勢 智 (久留米大·医・細菌)

われわれは，マイコプラズマが， Macrophage（M $\phi)$ からの Tumor necrosis factor の誘起能を有することを 報告してきた。本学会では実際に，Acholeplasma laidlawii を Meth A 接種 $\mathrm{BALB} / \mathrm{c}$ 系マウスに投与し, 明らかな抗腫瘍活性を認めたので報告する。

〔材料及び方法〕A. laidlawii を PPLO 液体培地で培 養し， 30,000g 遠心にて菌体を集めた。BALB/c マウ ス腹腔で継代した Meth A 細胞を皮下に接種し, 発生す る腫瘍の大きさを Geran の式で計測した。（短径 ${ }^{2} \times \mathrm{E}^{\mathrm{E}}$ 径/ 2 )

[結果] Meth A 接種後 7 日目に $A$. laidlawii $20 \mathrm{mg}$ （w. v.）を腹腔に投与すると 40-60\%のマウスで 60 日 後の観察でも完全に腫瘍の発生が認められなかつた。 たコントロール群での腫痬の大きさの比較でも 60-70 $\%$ の発育抑制が認められた。また $5 \mathrm{mg}$ 投与では，ほぼ 
コントロールと同じであり抑制効果は認められなかつ た。次に, OK432 誘導 M $\phi$ と Meth A, A. laidlawii を 混合し，皮下に接種して腫瘍の発生を観察した。 $A$. laidlawii 100r, 10r 存在下で明らかに，250 万接種 Meth A の腫瘍発生および，その増殖が抑制された。こ のことは, A. laidlawii が $\mathrm{M} \phi$ に強い抗腫瘍作用を付加 することを示唆している。

\section{I -8 Candida albicans $の$ germ tube 形成と菌} 体内 cyclic AMP

○長環, 浜高家尚子, 田中雅子, 上西秀則, 萩原 義郷（福岡歯大·口腔細菌）

Candida albicans 9 germ tube 発現における菌体内 cyclic AMP 量の関係について検討した結果 germ tube 発現には直接関係していないと思われる結果を得たので 報告する。

Candida albicans の対数期中期の菌を用い, 蒸留水中 37 C あるいは 0 C 1 時間の飢餓処理を行つた後, 2 種 類の germ tube 形成用培地 (Glc 培地, GlcNAc 培地) に移し $37 \mathrm{C}$ で反応を行つた。これらの培地中で, 高い germ tube 形成率を得るためには，37 C での飢餓処理 が必要であつた。菌体内 cyclic AMP 量は, 飢餓処理 1 時間後温度に関係なく約 4 倍増加した。さらに, germ tube 形成用培地に移した 1 時間後, Glc 培地, GlcNAc 培地の順に菌体内 cyclic AMP 量は急激な減少 を示した。germ tube 発現の準備は, この時期既に始 まつていると考えられることから, cyclic AMP 量の減 少は, cyclic AMP が germ tube 発現に直接関係しない ことを示唆する。

\section{I - 9 Candida albicans $の$ 付着と細胞表面疎水性} ○新見昌一, 神山章子, 徳永美知子（鹿児島大 $\cdot$ 歯 細菌)

Candida albicans の病原性発現に関与する因子は今の ところ不明であるが, 宿主細胞への付着は感染に必須で あると考えられている。今回は，この菌の臨床材料由来 株 (21 株) 之健康人由来株（19 株）扎よび教室保存株 （15 株）の 55 株を用いて各グループ間に付着能の相違 があるか否かをしらべた。ヒト頪粘膜上皮細胞への付 着：上皮細胞と菌を混合して $37 \mathrm{C} て ゙ 1$ 時間培養後, 上 皮細胞に付着した菌数を数えた。個々の菌株によつて大 きな差が認められたが, 臨床材料由来株の平均の付着能 と健康人由来株のそれとの間には相違はみられなかつ た。しかし教室保存株の平均の付着能は前の 2 グルー
プの半分以下の值しか示さなかつた。プラスチック表面 への付着 : ELISA 用ポリスチレンプレートに菌を入れ て 2 時間培養したのち, プレートの底に付着した菌の濁 度を測定して比較した。全体的に付着の程度は低く, 臨 床材料由来株, 健康人由来株, 教室保存株の間に差はみ られなかつた。それぞれの菌株の上皮細胞とプラスチッ クへの付着には相互関連性は認められなかつた。C albicans の細胞表面疎水性 : hexadecane への菌の移行 の程度でしらべたが，ほとんどの菌株が極めて低い值を 示した。菌の表面疎水性とポリスチレンへの付着につい てはさらに検討を要するが, 上皮細胞への付着との関連 性はないと考えられる。

\section{I - 10 Candida albicans のヒト㚘粘膜上皮細胞へ の付着}

○徳永美知子，新見昌一，小池紘民1）（鹿児島大 - 歯 ·細菌, 1)明石ビームテクノロジー)

Candida albicans のヒト煩粘膜上皮細胞への付着の初 期段階について cryo-SEM 法と凍結置換法を用いて微 細構造を観察した。C. albicans 3135 株（serotype A) を 酵母エキスを含むサブロ一培地に培養して得た静止期初 期の酵母形細胞を用い，上皮細胞は健康人の煩粘膜より 採取した。C. albicans の上皮細胞への付着は, 両細胞 を組織培養液中に混合して $37 \mathrm{C} て ゙ 1.5$ 時間振盪して行 わせた。この試料は液化プロパンで急速凍結して走查電 顕で観察し,さらに, 凍結試料を $\mathrm{OsO}_{4} /$ アトン $(-80 \mathrm{C})$ で凍結置換固定した後, 通法によつて包埋 · 薄切して透過電顕で観察した。C. albicans の酵母形に 混じつて germ tube を形成しているものが多数見られ た。Candida 細胞表層を覆つているケバ状線維構造は 上皮細胞の細胞膜突起部 (cell membrane interdigitations）に結合しているのが観察された。またC. albicans 自身の線維構造を介して菌同士が付着している像や，口 腔常在細菌の細胞表層に存在する微細線維を介して, 上 皮細胞とC. albicans とが付着しているのが観察された。 これらのことから, 菌表層のケバ状線維構造が上皮細胞 への付着に重要な役割を演じていると考えられる。さら に germ tube が上皮細胞内に侵入している像も認められ， C. albicans と上皮細胞の付着の初期段階に関する興味 深い所見が得られた。

I -11 NMR による Candida albicans ステロール 変異株のグルコース代謝の解析

○下川 修, 河野敬一1)，中山宏明（九大·歯・細 


\section{菌, 1)補綴 I )}

NMRによる生体内の代謝の研究法はその非破壊性に おいて従来の方法とはまつたく異なり代謝研究に新しい 視点を与えるものである。演者らはCandida albicans の ステロール変異株が呼吸活性の顕著な低下を示すことを 明らかにし，それはステロールの变化がミトコンドリア 膜の構造上の変化を通して機能障害を起こすことによる と考えてきた。今回は親株 (KD14) と変異株 $(\mathrm{KD}$ 4900)のグルコース代謝を ${ }^{13} \mathrm{C}$ NMR で解析することに より，呼吸活性低下が代謝系に及ぼす影響について調べ た。

嫌気条件では二株ともエタノール発酵をするのに対し 好気条件(通気)では二株は著しく異なる代謝を示した。 すなわち KD4900 はグルコース消費速度が KD14の 30 $\%$ に減少しトレハロースとマンニトールを顕著に蓄積 した。しかし KCN で電子伝達系を阻害するとグルコ一 ス消費速度は KD14 と同様になつた。これは KD4900 の代謝異常が電子伝達系と何らかの関連性をもつことを 示唆する。ステロールの変化による呼吸活性の低下は, 種々の代謝に影響を及ぼすようである。

\section{II - 1 Pseudomonas aeruginosa の萊膜}

○横山 哲, 梅田昭子, 天児和暢（九大·医 - 細菌）

緑膿菌は，アルギニン酸を主体としたムドイドの細胞 外への産生がその病原性に関与することが知られている が，大腸菌やVibrio vulnificusに存在するのと同じょら な構造の萊膜の存在は, 今まで知られていない。

今回われわれは急速凍結置換法を用い，緑膿菌を電子 顕微鏡的に観察を行つた。用いた菌株は臨床分離株 SAT 株（ムコイド産生十）および研究室株 K 株（ムコ イド産生一）である。結果は，SAT株で，菌体周囲に ムコイドとは異なる均一な繊維上構造物が観察され, こ れは菌体の洗浄によつて遊離しているムコイドを取り除 くことによつて，より明らかになつた。また $\mathrm{K}$ 株にも 同様の構造物が存在しており，大腸菌等で見られるもの と同様の萊膜と考えた。しかし臨床分離株のSAT 株は ムコイド維持培地上での継代培養中に，萊膜の産生が認 められなくなつた。これはこの臨床分離株における萊膜 の産生能が不安定である可能性が考えられた。萊膜の有 無による病原性の違いについても現在検討中であり, 併 せて報告する予定である。

\section{II－2 急速凍結置換法による黄色ブドウ球菌萊膜の 電顥的観察}

○有薗 剛，梅田昭子，天児和暢（九大·医 · 細菌） ブドウ球菌の萊膜は化学固定による影響を受け易いた め, 生理的微細構造の観察は難しい。今回われわれは, 急速凍結置換固定法によつて超薄切片を作製し, 莁膜保 有株と非保有株の電顕的観察を行つた。萊膜保有株とし て (Staphylococcus aureus Smith diffuse 株を，また，非 保有株として Smith compact 株を使用した。Heart infusion broth で培養した細菌を, 液体窒素にて冷却した銅 版に圧着し凍結させた。置換固定後, 包埋し, 超薄切片 を作製して日本電子 2000-EX 透過型電子顕微鏡にて観 察した。萊膜は樹枝状の構造を持ら, 従来のルテニウム レッド染色による像で認められた均一に近い構造とは異 なつていた。また, 萊膜非保有株の Smith compact 株 の細胞壁周囲にも極めて短い構造物が認められた。

次に抗タイコ酸抗体により, 菌体表面に認められた毛 羽状構造の検討を行つた。両株に抗タイコ酸抗体を作用 させ,プロテイン A-gold で標識した。これを急速凍結 置換法により超薄切片を得て電顕的観察を行つた。 Smith compact 株では菌体表層にほぼ均一に付着したプ ロテインA-gold が認められたが, Smith diffuse 株では それが認められず, 抗タイコ酸抗体は付着していなかつ た。このことから, Smith compact 株の表層にはタイ コ酸が露出しているのに対し Smith diffuse株の表層は 萊膜で覆われているためにタイコ酸は露出していないこ とが確認できた。抗原性の高いタイコ酸が菌体表層に露 出していないことは, 萊膜保有株の virulence の高さに 大きく関与しているものと思われた。

\section{II ー 3 SDS 処理による spirosome たんぱく局在 部位の検討}

○吉盛健, 小田 紘（鹿児島大·医·細菌）

Spirosome 産生菌の菌体を PBS 中で弱くソニケーシ ョンすると, 電顕で菌液中に spirosome を確認するこ とが出来る。しかし菌体を $1 \%$ SDS で処理後, 洗浄し た場合には，菌体が破壊されていないにもかかわらず, ソニケーションで spirosome が見られなくなる。これ はSDS が菌体の表面から spirosome たんぱくに作用し たと考えられ，解析を試みた。菌はPeptostreptococcus productus a-16株, グラム陽性無芽胞嫌気性桿菌 HD-17 株， E. coli B 株を用いた。菌体を $1 \%$ SDS 液に眯濁し て 4 時間静置し, PBS で 4 回洗浄後, PBS に懸濁し超 音波で完全に破壊して未破壊の菌を除き，15,000 rpm， 30 分の遠心をすることにより, 主として細胞壁と細胞 膜からなる沈渣が得られた。上清は凍結乾燥を行つた。 
対照として SDS 処理をしない菌で同様の処理を行い， これらの画分をSDS-PAGE にかけ比較を行つた。その 結果, SDS 処理群では沈渣のほうに spirosome たんぱ くが見られ，上清部分には少なかつた。またその沈渣を Triton X-100 で処理すると，その spirosom たんぱくが 見られなくなつた。これらのことから SDS の弱い作用 により spirosome たんぱくが細胞壁あるいは細胞膜に 結合したことが示唆された。

\section{II - 4 コレラ菌の赤血球疑集阻害因子}

OSumaruno, 江原雅彦, 宇都宮明剛, 一瀬休生, 霜 鳥翔一1)（長崎大·熱研・細菌， ${ }^{1}$ 九大·医短 ·微生 物)

コレラ菌の赤血球凝集素 (hemagglutinin) は Finkelstein Sによつて報告された soluble hemagglutinin (cholera lectin) および cell-associated hemagglutinin $の$ 2 種に大別されるが，詳細は不明なままである。コレラ 菌の小腸への定着能と in vitro での赤血球凝集能との間 に解離がみられる。cell-associated hemagglutin が定着 性と関連があるのか否か, hemagglutinin の調節機構は 如何なるものかについて検討を加えた。コレラ患者分離 株で HA 活性はないが鬼小腸へ定着能を有する TM9 株 より non-motilu mutant を作製した。そのらち T79-3, T79-6 は HA 活性および定着能を有していた。T79-6 株を TCG 寒天で $30 \mathrm{C}, 48 \mathrm{~h}$ 培養後, オムニミキサーで 菌表層を shearing して, その遠心上清から硫安 $40 \%$, 40-70\% cutをとり，それぞれを cellulofine sulfate affinity columnにかけ, crude hemagglutinin および hamagglutinin inhibitor fractionを分画し, 更に protein Pak300によるゲル濾過で分画した。 hemagglutinin inhibitor は $12 \mathrm{KDa}-20 \mathrm{KDa}$ の数種のたんぱくからなる分 画に認められた。

\section{II - 5 コレラ菌の赤血球疑集素}

○江原雅彦, Sumaruno, 宇都宮明剛, 一瀬休生, 霜 鳥翔一1（長崎大 · 熱研 · 細菌, ${ }^{1}$ 九大 · 医短 ·微生 物)

コレラ菌の赤血球凝集素，とりわけ cell-associated hemagglutinin については不明な部分が多く，この解明 はコレラ菌の小腸への定着能と共に極めて重要と思われ る。コレラ菌 K23-7 株 (non-motile, adhesive, HA positive）を TCG 寒天で $30 \mathrm{C}, 48 \mathrm{~h}$ 培養後, 菌体をオム キサーで shearing しその遠心上清の硫安 $40 \%$ cut に約 $90 \%$ の hemagglutinin が回収された。この $40 \%$ cut 分
画と, ヒト $\mathrm{O}$ 型血球 $(2 \%)$ とを等量ずつとつて赤血球 凝集反応を行い, その凝集赤血球を osmotic shock で溶 血後, さらに生食で 3 度遠心洗浄を行つて, 膜分画を 回収した。この膜分画中に含まれるコレラ菌表層由来た んぱくの解析を SDS-PAGE および Western blot で行つ た。

\section{II - 6 腸炎ビブリオの $\delta \mathbf{V P H}$ の病原性の検討}

○谷口初美, 小川みどり, 吉田真一, 大友信也 ${ }^{1)}$, 水 口康雄（産業医大・微生物, ${ }^{1}$ 大分県公衛センター）

神奈川現象陰性の腸炎ビブリオから分離された新しい 型の耐熱性溶血素 $(\delta \mathrm{VPH})$ の毒性について, 神奈川溶 血毒 (TDH) , 易熱性溶血素 (TLH) と比較検討した。 各溶血素の遗伝子と vector pUC9 との組換体プラスミ ドおよび vectorのみを有する $E$. coli $\mathrm{K} 12 \mathrm{C} 600$ を $\mathrm{NaCl}$ $0.5 \%$ 含有普通ブイヨンで 1 夜培養した。その培養上清 を 30-65\% 硫安で分画し, 約 100 倍に濃縮したものを 試料として用いた。今年の本総会で, マウスに $\delta \mathrm{VPH} 1$ $\mathrm{m} l$ を腹腔投与すると， 8-48 時間以内に 5 匹中 3 匹が 死亡し, 空腸, 回腸部位に变化があることを報告した。 そこで $\delta \mathrm{VPH} 1 \mathrm{ml}$ を経口的に投与した。1-4 時間後は 下痢症状が認められ, 後回復したが, 24 時間以内に 5 匹中 1 匹が死亡した。他のマウスは非常に衰弱してい たが生き残つた。その腸管は, 空腸から回腸にかけて, 浮腫之泥状便の貯溜が認められ, また麻疸性の腸閉塞症 が扣きていた。そこでマウスの腸管を切り出し, PBS $20 \mathrm{~m} l$ に浮遊させて, 各毒素を $1 \mathrm{ml}$ ずつ作用させた。 その結果, $\delta \mathrm{VPH}$ は, 5 分後には完全に腸管のぜん動 運動を止めた。これに対し, TDH, TLH, vector の場 合, まつたく影響が認められなかつた。また $\delta \mathrm{VPH} は$ L-cell に対する細胞障害性も有していた。

\section{II -7 食品の赤痢菌検查法の検討}

○霜鳥翔一, 天児和暢 1 ，小島夫美子（九大·医短 · 微生物, ${ }^{1)}$ 九大·医·細菌)

食品からの赤㢉菌検出が一般に困難なことはよく知ら れており, 現行法では食品 $1 \mathrm{~g}$ 当たり $10^{5} \sim 10^{6}$ 個以上 の赤痢菌污染でようやく検出可能とされている。この原 因として 1 つには食品の加工, 保存, 調理に基づく污 染菌の損傷によつてそれらが分離培地中に含をれる胆汁 酸塩に対して高い感受性を示すようになること，また Catalase 活性の低下を招来して自己 $\mathrm{H}_{2} \mathrm{O}_{2}$ が有害に作用 することなどが指摘されている。他の 1 つは, 食品材 料中の共存細菌が培養液中に産生する各種有機酸に対す 
る赤痢菌の弱抵抗性をあげることがでさる。今回われわ れは，1984 年に Mehlmanらによつて考案された赤痢 菌の増菌用培地およびその培養法に若干の追加改良を行 い, これを用いてとくにウニ, カキ等の海産生鮮魚介類 を対象とした赤麻菌の検出実験を行つた。 43 株の新旧 保存赤痢菌株を用いて調べたところ, 材料中の一般生菌 数に関係なく $10^{0} \sim 10^{3}$ 個の濃度範囲で接種した材料中 の菌を上記増菌培養法により検出できた。また，加熱処 理による損傷細胞において $\mathrm{H}_{2} \mathrm{O}_{2}$ 除去剤として加えた 1 $\%$ ピルビン酸ナトリウムは DHL 培地上の集落数を増加 させた。以上の結果からこの方法が海産食品の赤痢菌検 査にきわめて有用であることが示された。

\section{II - 8 胆汁酸 $7 \alpha$-脱水酸化反応陽性株について}

○高嶺房枝, 今村禎祐（琉球大·医·保健）

ヒト翼便より分離された胆汁酸の $7 \alpha$-脱水酸化陽性株 を用いて，胆汁酸代謝および生化学的性状について検討 した。分離された 5 株はすべてグラム陽性嫌気性桿菌 であつた。これらの株はズルシット，ガラクトース，ソ ルビット，キシロース，フルクトース，グルコースの 6 糖を分解しマンニットとマトースの分解性はわずかに異 なつていた。また，全株がカタラーゼ陽性株であつた。 グルコースからの脂肪酸の産生は酢酸のみであつた。こ れまで本菌株と類似の性状を示す $7 \alpha$-脱水酸化陽性菌の 報告はない。

growing cell において, 培養 1 日目でCAはそのほと んどが DCA に変換されるが， CDCA においては，培 養 6 日目でもわずか数 \%が LCA に変換されるにすぎな い。一方，UDCA はほとんど分解されなかつた。また， FAD の添加により， $7 \alpha$-脱水酸化反応が促進される菌 株とされない菌株とがあつた。そのほか，これらの菌株 は $7 \alpha$-脱水素活性を示した。

\section{II - 9 ハマチレンサ球菌感染症原因菌, Strepto-} coccus sp., 由来 $\mathbf{R}$ プラスミドの莧風耐性击伝子につい $\tau$

○高見幸司, 青木 宙, 北尾忠利（宮崎大 · 農 · 水産 衛生)

八マチレンサ球菌感染症由来, 非溶血性 Streptococcus sp. の R プラスミドがコードする EM, TC 耐性遺伝子に ついて検討した。

pSY8632（24.1 Kb; EMr, TCr) より EM 耐性遺伝子を Streptococcus faecalis の系でクローン化した。 pSY8632 の EM 耐性遺伝子は $E$. coli で発現しなかつた。コロ
ニーハイブリダイゼーションの結果， EM，TCあるい は EM, CP に高度耐性を示したStreptococcus sp. は, pSY8632 の EM 耐性遺伝子と相同性を示したが，中等 度耐性株および薬剂感受性株は相同性を示さなかつた。 pSY8632 の EM 耐性遺伝子は 3 つの open reading frame（ORF1-ORF3）より構成され，S. faecalis 由来の Tn917 と全体的に高い相同性を示したが, leader peptideである ORF1については，E. coli 由来 pIP1527 が コードする MLS (macrolide-lincosamide-streptogramin type B) 耐性遺伝子のそれと似ていた。ORF2について は既知の MLS 耐性遺伝子と高い相同性があり, 同一の 耐性機構 (23S rRNA adenine dimethylation) ではない かと考えられた。

pSY8632 は E. coli で複製可能であつたが in vivoで deletion が確認された。pSY8632の TC 耐性遺伝子は E. coli で発現した。

\section{II - 10 豚鼻腔由来 Pasteurella multocida の R プ ラスミドの検索}

$\bigcirc$ 牛島稔大, 永野理恵, 河合 透, 種子野章, 花木伥 磨, 江藤正信（化血研）

1988 年に国内 16 県下の豚鼻腔内より分離した $P$. multocida $\mathrm{D}$ 型菌 119 株について薬剂感受性, 皮膚壊死 毒素 (DNT) 産生能およびプラスミド保有状況を調べ た。

その結果 1 ） SM, SA, CP, KM, OTCの各薬剤に対す る耐性株の存在が認められた。薬剤耐性パターンでは単 剂耐性；SA (4\%), CP (7\%), OTC (0.8\%) 2 剂耐性； SM-SA (18.5\%), CP-SA (2.5\%), OTC-SA (0.8\%) 3 剂耐性 ; SM-CP-SA (5.9\%), KM-CP-SA (2.5\%), KMSM-SA (1.7\%), OTC-SM-SA (1.7\%) が観察された。 一方, 薬剂非耐性株は $54.6 \%$ であつた。大腸菌 C 株を 受容菌とする接合伝達および大腸菌 $\mathrm{C} 600$ 株を受容菌と する形質転換により $\mathrm{R}$ プラスミドを検索したところ， 非伝達性の $\mathrm{R}$ プラスミドが $\mathrm{SM}, \mathrm{KM}$ 耐性においてそれ ぞれ検出された。

2）DNT 産生は，90 株（75\%) に認められ，5ち $91 \%$ がラムダ Hind III 消化断片の第 6 断片と移動度の

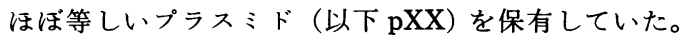
DNT 非産生株 29 株はいずれもこの pXXを保有してい なかつた。そこでプラスミドフリーDNT（一）の野生株 を受容菌とし， SM 耐性を有し， pXXを有する $\mathrm{DNT}(+)$ 株を供与株とした接合伝達を試みたところ， $\mathrm{SM}$ 耐性プラスミドとともにこれらのプラスミドを受け 
取つたトランスコンジュガントが得られたが，DNT 産 生能は獲得していなかつた。また，プラスミド非保有の DNT 産生株も存在するので, DNT はプラスミド性の 発現形質ではないと推察された。

\section{II -11 レイ菌線毛遺伝子の解析}

○守屋哲博, 山本松男, 天児和暢（九大 · 医 - 細菌)

レイ菌の持つ線毛は，MSHA (SMF1), MRHA (SMF2) および血球凝集性を持たない cryptic な線毛 （SMF3）に大別できる。今回はレイ菌 US5 株の保有す るSMF3について, その線毛の構成たんぱくと遺伝子 構造について検討した。

$s m f 3$ は US5 株においてはsmf1 の約 10kb 離れた領 域に位置し, トランスポゾンによる解析から他の線毛遺 伝子と同様に複数の遺伝子で構成されていることが明ら かになつた。smf3 はUS5 株では発現していず, 菌体 内で線毛たんぱくの合成もなされていないことがウェス タンブロットで確認された。しかし，このSMF3を発 現している株は他のレイ菌にも見当らなかつたが， $s m f 3$ は US5 株以外のレイ菌にも cryptic な状態で存在 しているものと思われた。SMF3 線毛サブュニットの $\mathrm{N}$ 末端のアミノ酸配列とアミノ酸組成を調べたところ, $\mathrm{N}$ 末端のアミノ酸配列は既知の線毛とはまつたく異な つており，またサブニニットにはシステインが含まれて いず， S-S 結合による三次元構造を持たない線毛であ ることが判明した。

II -12 新たにクローニングした Aeromonas hydrophila の溶血素遗伝子について

○広野育生, 青木 宙, 北尾忠利（宮崎大 - 農 - 水産 衛生)

われわれは今年の細菌学会総会で, Aeromonas hydrophila の病原性因子の 1 つである溶血素遺伝子のク ローニングについて報告した。今回は同一株の遺伝子ラ イブラリーより新たに溶血素遺伝子を見つけたので報告 する。

A. hydrophila ATCC7966 株の遺伝子ライブラリーは, 染色体 DNA Sau3AI で部分分解し, ベクター charomid 9-28をBamHI で消化しライゲーション後, in vitro パッケージングを行いE. coli $\mathrm{DH} 1$ 株に形質転換 し, 血液寒天平板でスクリーニングを行つた。この遺伝 子ライブラリーより溶血反応を示すクローンを得た。こ のクローンの挿入断片は約 $17 \mathrm{~Kb}$ であつた。この断片を 種々の制限酵素で消化しサブクローニングした結果,
$S p h \mathrm{I}$ 約 $2.5 \mathrm{~Kb}$ 断片上に溶血素遺伝子が存在することが 確認された。今回得られたクローンと前回報告したク ローンとはハイブリダイゼーションの実験より異なる遺 伝子であることを確認した。また，今回得られたクロ一 ンは前回報告したクローンより血液寒天平板上で明瞭に 溶血環を示した。さらに由来の異なる A. hydrophila と のコロニーハイブリダイゼーションの結果より, 人由 来, 魚由来共にこの遺伝子をるつ株が存在することが確 認された。

III-13 大腸菌 RecQ たんぱくの精製およびその活 性について一DNA 依存性 ATPase 活性と helicase 活性一

$\bigcirc$ 梅津桂子, 中山浩次, 中山宏明 (九大 ·歯・細菌) $r e c Q$ 遺伝子は大腸菌に护ける遺伝的組換光機構の $\operatorname{RecF}$ 経路の 1 遺伝子で, その変異は細胞を無チミン死 抵抗性にする。 recQ 遺伝子は GTG を開始コドンとし promoter, SD 配列も典型的なものではないため, sitedirected mutagenesis を用いて, lac 遺伝子の promot$\mathrm{er} / \mathrm{SD}$ 領域から開始コドンATG までの DNA 断片と $r e c Q$ 遺伝子の 2 番目のコドン以降の DNA 断片を繋い だ形の遺伝子を multicopy plasmid 上に持つ RecQ overproducerを作製した。この plasmid を持つ細胞より ssDNA-cellulose chromatography, 硫安分画, ゲル濾過, hydrophobic chromatography の過程を経て RecQたん ぱくの精製を行い, 銀染色したSDS/PAGE で単一なバ ンドを示し， $\mathrm{N}$ 末端アミノ酸配列およびアミノ酸組成 が DNA 配列からの予想と一致する標品を得た。この標 品について活性を検討したところ，DNA 依存性のAT一 Pase 活性, おょび 2 本鎖 DNA を巻き戻す DNA helicase 活性が認められた。この DNA の巻き戻しは, 他の helicase と異なり必ずしも 1 本鎖 DNA の導入部を 必要とせず，平滑末端を有する直鎖状 2 本鎖 DNA も基 質とすることができた。以上の結果から RecQ たんぱく は遺伝的組換えに際し, strand transfer の基質となる $3^{\prime}$ 末端を持つ 1 本鎖 DNA p strand gap の形成に寄与 していることが示唆された。

\section{II - 14 チミン飢餓の大腸菌染色体 DNA への影 響 : パルスフィールド電気泳動法による解析}

草野好司, ○中山浩次, 中山宏明（九大·歯・細菌） 1954 年 Cohen と Barnerにより, 大腸菌に扔いて無 チミン死が報告されて以来, 35 年経た現在に沶いても なおその致死の機構については明らかでない。われわれ 
は無チミン死抵抗性変異株の研究等から, 遺伝的組換兄 の $\operatorname{RecF}$ 経路に位置する遺伝子群の一部が無チミン死成 立に関係することを解明してきた。一方, 鮎沢らはマウ ス細胞をチミン飢餓にさらすと， $50 \sim 200 \mathrm{~kb}$ の DNA 断片が染色体より生じることを発見した。大腸菌に拈い てもチミン飢餓により二本鎖切断が惹起されるといら報 告もあり, 今回は大腸菌染色体 DNA の構造にチミン飢 餓がどのように影響を与えるかをパルスフィールド電気 泳動法 (PFGE) を用いて解析した。その結果, 以下の ことがわかつた。
1 ）大腸菌においては，チミン飢餓処理後も少なくと も $2,000 \mathrm{~kb}$ 以下の直鎖二本鎖 DNA は検出されなかつ た。

2 ）チミン飢餓処理後, 染色体 DNA を $X b a \mathrm{I}$ 制限酵 素で切断した後，PFGEを行らと，原点にとどまる（泳 動しない）染色体 DNA の量が増加した。

3 ）さらに，DNA 複製の origin（oriC）を含む $X b a \mathrm{I}$ 断片は，他の領域と比して顕著に電気泳動不能となり原 点にとどまつた。 